RECORDS OF PHARMACEUTICAL
AND BIOMEDICAL SCIENCES

\title{
Green UV Absorbance Ratio Method for Determination of Eprosartan and Hydrochlorothiazide
}

\author{
Khaled A. Marghany ${ }^{\text {a }}$, Randa A. Abdel salam ${ }^{\text {b }}$, Ghada M. Hadad ${ }^{\text {, Elsayed A. Ibrahim }}{ }^{\text {b }}$ \\ ${ }^{a}$ Ministry of Health, Directorate of Health Affairs, Ismailia Health Administration, Egypt. \\ ${ }^{b}$ Department of Pharmaceutical Analytical Chemistry, Faculty of Pharmacy, Suez Canal \\ University, Ismailia, Egypt.
}

Received on: 02. 11. 2020

Revised on: 26. 11. 2020

Accepted on: 01. 12. 2020

*Correspondence Author:

E-mail address:

Khaledabdelnaser_22@pharm.suez.edu.eg

\begin{abstract}
In this study, novel approach for quantitative determination of eprosartan mesylate (EPR) and hydrochlorothiazide (HCTZ) by green UV absorbance ratio method. The choice of green solvents was based on GSK solvent selection guide, the green UV absorbance ratio method was used for quantitation of studied compounds in their pharmaceutical formulations. The aim of this work is to develop sensitive method to estimate HCTZ and EPR by using UV absorbance ratio method at $231 \mathrm{~nm}$ as isoabsorptive point (isosbestic point) and $271 \mathrm{~nm}$ as max wavelength of HCTZ, the method was validated according to ICH guidelines (Guideline, 2005).This method facilitates to any analyst in industrial field to quantify any formula containing EPR or HCTZ by precise, sensitive, reliable, accurate and fully validated method without use of hazardous toxic organic solvents. The method was simple, direct and no derivatization step was needed. The method was successfully applied to the analysis of studied drugs in their commercial pharmaceutical products.
\end{abstract}

Keywords: Green Analytical Chemistry; Absorbance ratio method; ICH.

\section{Introduction}

EPR and HCTZ are important drugs used as antihypertensive medications. So, determination of these APIs is of great importance in analytical field, many UV spectrophotometric methods are used for determination of EPR and HCTZ but rely on use of large amounts of toxic hazardous solvents and generate large amount of toxic hazardous waste products. An absorbance ratio method have been developed for the estimation of EPR and HCTZ in pharmaceutical products (Anandakumar et al., 2011).

Two new simple and selective assay methods have been presented for the analysis of EPR and HCTZ in pharmaceutical formulations. The first method is based on first-derivative ultraviolet 
spectrophotometry with zero-crossing measurements at 246 and $279 \mathrm{~nm}$ for EPR and HCT, respectively. The second method involved isocratic RP-HPLC (Hacioglu \& Onal, 2012).

An HPLC-PDA method was developed and validated for the determination of HCTZ in bulk and pharmaceutical formulation (Mohammed \& Mohammed, 2016). Rajamahanti et al developed and validated an isocratic RP-HPLC method for the simultaneous determination of EPR and HCTZ in their binary mixtures of pharmaceutical dosage form preparation (Rajamahanti et al., 2017), another HPLC method was developed for determination of EPR and its impurities by Babu et al (Chandana et al., 2016). Hermann TW, et al developed method provides efficient separation of HCTZ from chlorothiazide, allowing the chlorothiazide to be used as internal standard, and potential allowing HCTZ to be used as an internal standard for quantitation of chlorothiazide (Tw, 2018). A validated ultra-performance liquid chromatography mass spectrometric method (UPLC-MS/MS) was used by Singh et al for the simultaneous quantitation of candesartan and HCTZ in human plasma. The analysis was performed on UPLCMS/MS system using turbo ion spray interface. Negative ions were measured in multiple reaction monitoring (MRM) mode (Singh et al., 2014). A sensitive and selective method has been developed by Shah et al for the simultaneous determination of amlodipine, valsartan and HCTZ in human plasma by liquid chromatography-tandem mass spectrometry (LC-MS/MS). The analytes and their deuterated analogs were quantitatively extracted from $100 \mu \mathrm{L}$ human plasma by solid phase extraction (Shah et al., 2017).

UV Spectrophotometric method for determination of EPR in bulk and its tablet formulation based on measurement of the absorbance of EPR solution in methanol: phosphate buffer $\mathrm{pH} 7.4$ (10:90) at 293 $\mathrm{nm}$ in wavelength length of 200-400nm (Bhupendra et al., 2016).

Green analytical chemistry is the new trend toward which the world is heading in chemistry, as analytical methodology implement and produce large amount of toxic hazardous solvents the use of chemicals and solvents harmful to environment must be minimized and replaced by eco-friendly solvents, and this is one of the twelve green analytical chemistry principles.

The simultaneous determination of EPR and HCTZ by green UV absorbance ratio method was not reported.

The aim of this work is to develop sensitive method to estimate HCTZ and EPR by using UV absorbance ratio method at $231 \mathrm{~nm}$ as isoabsorptive point (isosbestic point) and $271 \mathrm{~nm}$ as max of HCTZ, the method was validated according to ICH guidelines.

This method facilitates to any analyst in industrial field to quantify any formula containing EPR or HCTZ by precise, sensitive, reliable, accurate and fully validated method without use of hazardous toxic organic solvents.

\section{Materials and methods}

\subsection{Standards, solvents, and reagents}

Pharmaceutical grade of HCTZ (99.0\%) was supplied by Amoun (El-Obour city, Egypt). EPR (99.4\%) was supplied by Hochester (10th of Ramadan, Egypt).

Ethanol HPLC grade "Merck", was purchased from Cornell lab company (Cairo, Egypt). Milli-Q water was kindly supported by HPG Company (Cairo, Egypt).

Teveten plus $600 / 25 \mathrm{mg}$ tablets which is labelled to contain $600 \mathrm{mg}$ of EPR and $25 \mathrm{mg}$ HCTZ (Abott), was purchased from the Egyptian drug market.

\subsection{Stock standard solution}

$60 \mathrm{mg}$ of EPM and $2.5 \mathrm{mg}$ of HCT were accurately weighed separately and transferred to two different $100 \mathrm{ml}$ volumetric flasks.

Each drug was dissolved in ethanol and made up to the mark with the same solvent. The standard stock solutions contain $600 \mu \mathrm{g} / \mathrm{ml}$ of EPM and $25 \mu \mathrm{g} / \mathrm{ml}$ of HCTZ.

\subsection{Working standard solution and calibration curve standards}

Dilute the previous stock standard solutions to reach final concentration of $6-72 \mu \mathrm{g} / \mathrm{ml}$ of EPR and $0.25-10 \mu \mathrm{g} / \mathrm{ml}$ of HCTZ.

One to six milliliters of standard stock solution of EPR and 0.5-5.0 ml standard stock solution of HCTZ were transferred into a series of six $100 \mathrm{ml}$ volumetric flasks separately and made up to mark with ethanol and water (1:1). The absorbance of 
Different concentrations of solutions were measured at $271 \mathrm{~nm}$ and $231 \mathrm{~nm}$ against solvent as blank. The calibration curve was plotted using concentration against absorbance. The solutions were found to be linear with the concentration range of $6-72 \mu \mathrm{g} / \mathrm{ml}$ of EPR and $0.25-10 \mu \mathrm{g} / \mathrm{ml}$ of HCTZ. The procedure was repeated for six times.

Different mixtures of the two drugs were prepared by transferring different volumes of EPR and HCTZ from working standard solutions into $100 \mathrm{ml}$ volumetric flasks and diluting to volume with diluent. The concentrations of both EPR and HCTZ were determined by measuring the absorbance of the prepared mixtures at $271 \mathrm{~nm}$ and $231 \mathrm{~nm}$ by using absorbance ratio method.

\subsection{Sample Preparation:}

Twenty tablets were weighed accurately and average weight was calculated. The tablets were triturated to a fine powder. An accurately weighed quantity of tablet powder equivalent to $60 \mathrm{mg}$ of EPR and $2.5 \mathrm{mg}$ HCTZ was weighed and transferred into $100 \mathrm{ml}$ volumetric flask and added a minimum quantity of ethanol to dissolve the substance and made up to the volume with the same solvent $(600 \mu \mathrm{g} / \mathrm{ml}$ EPR and $25 \mathrm{mg}$ HCTZ). The solution was sonicated for $15 \mathrm{~min}$ and centrifuged for $5 \mathrm{~min}$ at $4000 \mathrm{rpm}$. The clear supernatant liquid was separated and filtered through $0.45 \mu \mathrm{m}$ nylon syringe filter.

From the clear solution, further dilutions were made with diluent to obtain solutions of EPR and HCTZ in the studied concentration ranges. The absorbance was measured at their selected wavelengths and the concentrations of two drugs were estimated by using absorbance ratio method.

\subsection{Instrumentation and apparatus}

The determination was performed using spectrophotometer Shimadzu UV-1800 by using quartz cuvette with $1 \mathrm{~cm}$ path length. The results were processed by using UV probe software.

\section{Results and discussion}

Assume that HCTZ is drug X and EPR is drug Y, according to Q-Absorption ratio method, use the ratio of absorption at two selected wavelengths. One is at iso-absorptive point and other being the $\lambda \max$ of one of the two components.
To determine the unkown concentration of HCTZ (Cx) and EPR (Cy) use equations 8 and 9, those equations were constructed as described below, using the relationship ax1=ay1 at $\lambda 1$ and $\mathrm{L}=1$, where ax 1 and ay 1 are absorptivities of $\mathrm{X}$ and $\mathrm{Y}$ at isosbestic point $(\lambda 1)$ using cuvette with path length $1 \mathrm{~cm}$. Equations are;

At $\lambda 1 \mathrm{~A} 1=\operatorname{ax} 1 \mathrm{Cx}+\operatorname{ax} 1 \mathrm{Cy}$ (because ax1=ay1) (1)

At $\lambda 2 \mathrm{~A} 2=\mathrm{ax} 2 \mathrm{Cx}+\operatorname{ay} 2 \mathrm{Cy}$

Dividing equation (2) by (1), we get

$\mathrm{A} 2 / \mathrm{A} 1=(\mathrm{ax} 2 \mathrm{Cx}+\mathrm{ay} 2 \mathrm{Cy}) /(\operatorname{ax} 1 \mathrm{Cx}+\mathrm{ax} 1 \mathrm{Cy})$ (3)

\section{Let $\mathrm{Cx} /(\mathrm{Cx}+\mathrm{Cy})=\mathrm{Fx} \& \mathrm{Cy} /(\mathrm{Cx}+\mathrm{Cy})=\mathrm{Fy}$}

Dividing Equation (3) by $\mathrm{Cx}+\mathrm{Cy}$, we get

$\mathrm{A} 2 / \mathrm{A} 1=(\operatorname{ax} 2 \mathrm{Fx}+\mathrm{ay} 2 \mathrm{Fy}) /(\operatorname{ax} 1 \mathrm{Fx}+\mathrm{ax} 1 \mathrm{Fy})$

But Fy $=1-$ Fx

$\mathrm{A} 2 / \mathrm{A} 1=(\mathrm{ax} 2 \mathrm{Fx}+\mathrm{ay} 2-\mathrm{ay} 2 \mathrm{Fx}) / \mathrm{ax} 1$

$\mathrm{A} 2 / \mathrm{A} 1=(\operatorname{ax} 2 \mathrm{Fx} / \mathrm{ax} 1)-(\operatorname{ay} 2 \mathrm{Fx} /$ ay 1$)+($ ay2/ay 1$)$ (because ax1=ay1)

Let ax $2 / \mathrm{ax} 1=\mathrm{Qx}$, ay $2 / \mathrm{ay} 1=\mathrm{Qy} \& \mathrm{~A} 2 / \mathrm{A} 1=\mathrm{QM}$

So, $Q M=F x Q x-F y Q y+Q y$

$\mathrm{Fx}=(\mathrm{QM}-\mathrm{Qy}) /(\mathrm{Qx}-\mathrm{Qy})$

This equation gives the fraction of mixture that determine the absolute concentration of $\mathrm{X}$ and $\mathrm{Y}$.

$\mathrm{Cx} /(\mathrm{Cx}=\mathrm{Cy})=(\mathrm{A} 2 / \mathrm{A} 1)-($ ay2/ay1)$/($ ax2/ax1 $)-($ ay2/ay 1)

Both equation (5) \& (6) gives the fraction, rather than the concentration of $\mathrm{X}$ and consequently of $\mathrm{Y}$ in the mixture in the term of absolute ratio. As, these are independent of concentration

only approximate rather than accurate. If the absolute concentration of $\mathrm{X} \& \mathrm{Y}$ than rearrange

equation (1), the following equation will be obtained

$\mathrm{Cx}+\mathrm{Cy}=\mathrm{A} 1 / \mathrm{ax} 1$

From equation (6) \& (7), the following equation will be obtained 


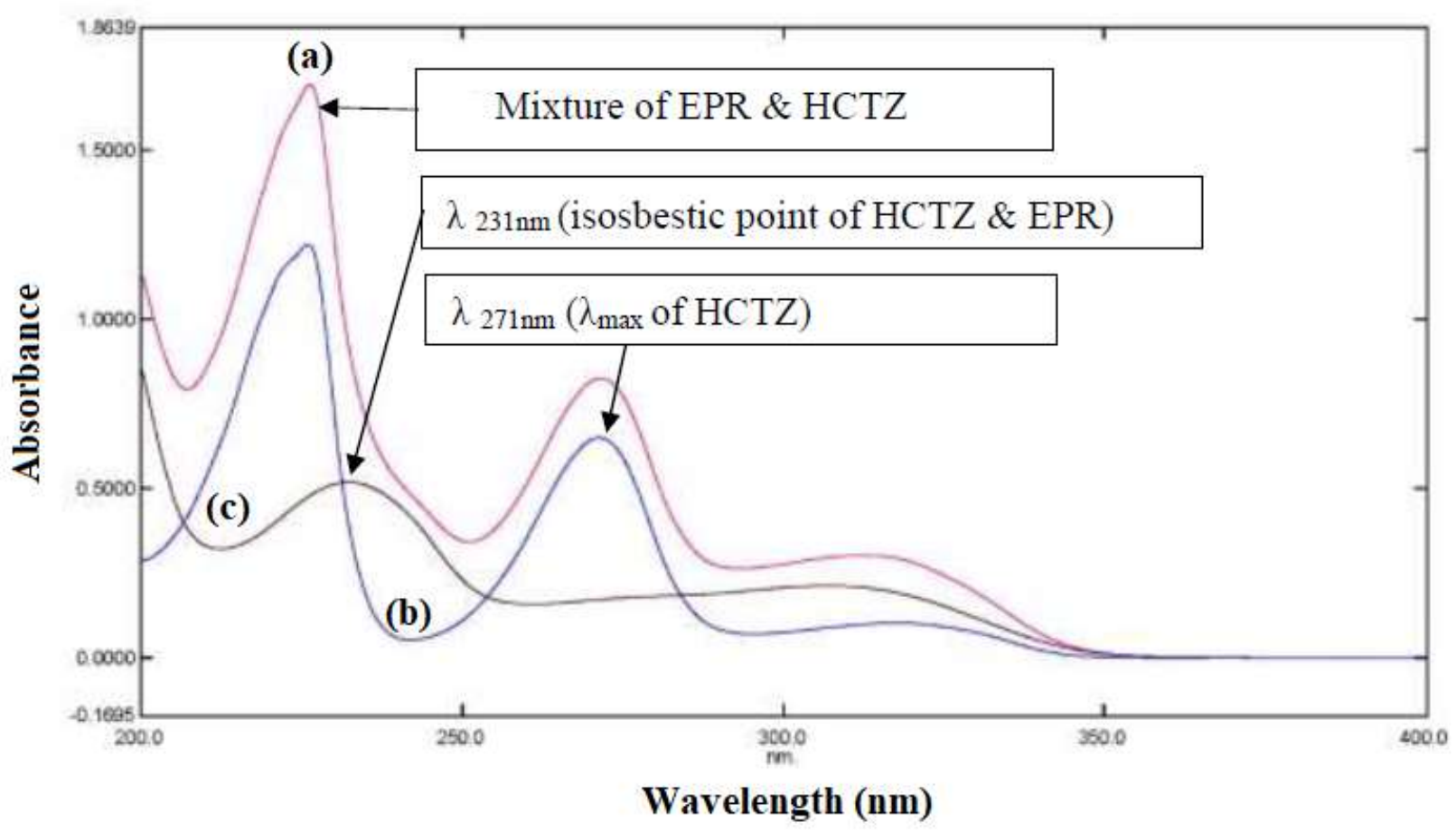

Figure 1: Overlay of zero order spectra of (a) synthetic mixture, (b) HCTZ, and (c) EPR at concentration $10 \mu \mathrm{g} / \mathrm{ml}$ of each extinguish isosbestic point (a) at $231 \mathrm{~nm}$ and other point which represent maximum of HCTZ spectrum (b) at 271 $\mathrm{nm}$.

$$
\begin{aligned}
& \mathrm{Cx} /(\mathrm{A} 1 / \mathrm{ax} 1)=(\mathrm{QM}-\mathrm{Qy}) /(\mathrm{Qx}-\mathrm{Qy}) \\
& \mathrm{Cx}=\{(\mathrm{QM}-\mathrm{Qy}) /(\mathrm{Qx}-\mathrm{Qy})\}^{*}(\mathrm{~A} 1 / \mathrm{ax} 1) \ldots \ldots \ldots \ldots(8) \\
& \& \quad \mathrm{Cy}=\quad\{(\mathrm{QM}-\mathrm{Qx}) /(\mathrm{Qy}-\mathrm{Qx})\}^{*} \quad(\quad \mathrm{~A} 1 / \mathrm{ay} 1) \\
& \ldots \ldots \ldots \ldots \ldots(9)
\end{aligned}
$$

$\mathrm{QM}=$ Absorbance of mixture at $271.0 \mathrm{~nm}(\mathrm{~A} 2) /$ Absorbance of mixture at $231.0 \mathrm{~nm}(\mathrm{~A} 1)$,

$\mathrm{Qx}=$ Absorptivity of HCTZ at $271.0 \mathrm{~nm} /$ Absorptivity of HCTZ at $231.0 \mathrm{~nm}$,

Qy = Absorptivity of EPR at $271.0 \mathrm{~nm} /$ Absorptivity of EPR at $231.0 \mathrm{~nm}$,

$\mathrm{A} 1=$ Absorbance of mixture at Isobestic point, ax 1 $=$ Absorptivity of HCTZ at Isobestic point, ay1 $=$ Absorptivity of EPR at Isobestic point,

$\mathrm{Cx}=$ Concentration of HCTZ, $\mathrm{Cy}=$ Concentration of EPR.

Finally equation $(8 \&$ \& $)$ gives the absolute concentration value of drug $\mathrm{X} \& \mathrm{Y}$.

$$
\begin{aligned}
& \mathrm{Cx} /(\mathrm{A} 1 / \mathrm{ax} 1)=(\mathrm{QM}-\mathrm{Qy}) /(\mathrm{Qx}-\mathrm{Qy}) \\
& \mathrm{Cx}=\{(\mathrm{QM}-\mathrm{Qy}) /(\mathrm{Qx}-\mathrm{Q} y)\}^{*}(\mathrm{~A} 1 / \mathrm{ax} 1)
\end{aligned}
$$$$
\& \quad \mathrm{Cy}=\{(\mathrm{QM}-\mathrm{Qx}) /(\mathrm{Qy}-\mathrm{Qx})\}^{*}
$$

A1/ay1) (9)

$\mathrm{QM}=$ Absorbance of mixture at $271.0 \mathrm{~nm}$ (A2) / Absorbance of mixture at $231.0 \mathrm{~nm}$ (A1),

$\mathrm{Qx}=$ Absorptivity of HCTZ at $271.0 \mathrm{~nm} /$ Absorptivity of HCTZ at $231.0 \mathrm{~nm}$,

Qy = Absorptivity of EPR at $271.0 \mathrm{~nm} /$ Absorptivity of EPR at $231.0 \mathrm{~nm}$,

$\mathrm{A} 1=$ Absorbance of mixture at Isobestic point, $\mathrm{ax} 1$ = Absorptivity of HCTZ at Isobestic point, ay1 $=$ Absorptivity of EPR at Isobestic point,

$\mathrm{Cx}=$ Concentration of HCTZ, $\mathrm{Cy}=$ Concentration of EPR.

Finally equation $(8 \&$ \& $)$ gives the absolute concentration value of drug $\mathrm{X} \& \mathrm{Y}$. 
Table 1: System suitability results for determination of $1 \mu \mathrm{g} / \mathrm{ml}$ of HCTZ and $6 \mu \mathrm{g} / \mathrm{ml}$ of EPR.

\begin{tabular}{|c|c|c|c|}
\hline API & $\begin{array}{c}\text { Mean found conc. } \\
\mu g / m \boldsymbol{l}\end{array}$ & Mean recovery \pm SD & RSD \\
\hline \hline HCTZ & 1.005 & $100.50 \pm 0.11$ & 0.109 \\
\hline EPR & 6.156 & $102.60 \pm 0.31$ & 0.302 \\
\hline
\end{tabular}

\subsection{Methodology}

Absorption ratio method uses the ratio of absorptions of two selected wavelength, one of which is iso-absorptive point and other being the $\lambda \max$ of one of the two components. From the overlain spectra of two drugs (as shown in figure 1), it shows that EPR and HCTZ having iso-absorptive point at $231 \mathrm{~nm}$. The second wavelength used is 271 $\mathrm{nm}$, which is the $\lambda$ max of HCTZ. Working standard solutions having concentration $0.25,0.5,1,1.5,2$, and $3 \mu \mathrm{g} / \mathrm{ml}$ for HCTZ and 6, 12, 24, 36, 48 and $72 \mu \mathrm{g} / \mathrm{ml}$ for EPR, were prepared and the absorbance at $231 \mathrm{~nm}$ (iso-absorptive wpoint) and $271 \mathrm{~nm}$ ( $\lambda \max$ of HCTZ) were measured and absorptivity coefficient were calculated using calibrations curve.

The concentration of two drugs in the mixture can be calculating by using the equation $(8 \& 9)$, we get $\mathrm{Cx}=\{(\mathrm{QM}-\mathrm{Qy}) /(\mathrm{Qx}-\mathrm{Qy})\} *(\mathrm{~A} 1 / \mathrm{ax} 1)$

$$
\mathrm{Cy}=\{(\mathrm{QM}-\mathrm{Qx}) /(\mathrm{Qy}-\mathrm{Qx})\}^{*}(\mathrm{~A} 1 / \mathrm{ay} 1)
$$

\subsection{System suitability:}

The standard solution was prepared as described in the analytical method and was measured six times by UV from the same standard solution $1 \mu \mathrm{g} / \mathrm{ml}$ of HCTZ and $6 \mu \mathrm{g} / \mathrm{ml}$ of EPR. The results were tabulated, the percentage relative standard deviation was calculated. The low value of RSD obtained $(<2.0)$ for all components of the standards showed that the system was suitable. The results were shawn in (Table 1).

\subsection{Validation of the method:}

\subsubsection{Precision:}

\subsubsection{Repeatability results:}

Percentage RSD of mean recovery in accuracy results was calculated. The low value of RSD obtained $(<2.0 \%)$ indicated that the method was repeatable.

\subsubsection{Intermediate precision (Analyst to analyst / Day to day):}

The standard solution was prepared in different days by different analysts as described in the analytical method.

To an accurately weighed quantity of the tablet powder equivalent to $30 \mathrm{mg}$ of EPR and $1.25 \mathrm{mg}$ HCTZ, 7.5, 15 and $22.5 \mathrm{mg}$ of EPR and 2.5, 5 and $7.5 \mathrm{mg}$ of HCTZ raw materials were added into a series of $100 \mathrm{ml}$ volumetric flasks by the first analyst in the first day and another samples were prepared in the second day by the second analyst. The results were tabulated and RSD for assay of eighteen samples were calculated. The low value of the percentage relative standard deviation (RSD < 3.0) of samples indicated that the method was precise. The results were shawn on (Table 2).

\subsubsection{Reproducibility (Instrument to instrument/Lab to lab):}

The standard solution was prepared in different laboratories as described on analytical method and was measured on different instruments.

To an accurately weighed quantity of the tablet powder equivalent to $30 \mathrm{mg}$ of EPR and $1.25 \mathrm{mg}$ HCTZ, 7.5, 15 and $22.5 \mathrm{mg}$ of EPR and 2.5, 5 and $7.5 \mathrm{mg}$ of HCTZ raw materials were added into a series of $100 \mathrm{ml}$ volumetric flasks by the same analyst using two different instruments in 2 different laboratories. The assay results were tabulated and percentage RSD for six samples were calculated. The low value of percentage relative standard deviation $(<3.0)$ of samples indicated that the method was reproducible. The results were shown in (Table 2). 
Table 2: Precision results for determination of three different concentrations of each of studied analytes by UV absorbance ratio method.

\begin{tabular}{|c|c|c|c|c|c|c|c|c|c|c|}
\hline \multirow{4}{*}{ Drug } & \multirow{2}{*}{\multicolumn{2}{|c|}{ Actual conc. }} & \multicolumn{8}{|c|}{ Measured concentration Intermediate precision } \\
\hline & & & \multicolumn{4}{|c|}{ Analyst to analyst/Day to day } & \multicolumn{4}{|c|}{ Instrument to instrument/ Lab to lab } \\
\hline & $\begin{array}{c}U V \\
\text { Shimadzu }\end{array}$ & $\begin{array}{c}U V \\
\text { Jenway }\end{array}$ & $\begin{array}{l}\text { 1st Analyst } \\
\text { found conc }\end{array}$ & $R S D$ & $\begin{array}{l}\text { 2nd Analyst } \\
\text { found conc }\end{array}$ & $R S D$ & $\begin{array}{l}\text { UV Shimadzu } \\
\text { fond conc }\end{array}$ & $R S D$ & $\begin{array}{l}\text { UV Jenway } \\
\text { found conc }\end{array}$ & $R S D$ \\
\hline & $\left(\mu g m L^{-1}\right)$ & $\left(\mu g m L^{-1}\right)$ & $\left(\mu g m L^{-1}\right) \pm S D$ & & $\left(\mu g m L^{-1}\right) \pm S D$ & & $\begin{array}{c}\left(\mu g m L^{-1}\right) \\
\pm S D \\
\end{array}$ & & $\begin{array}{c}\left(\mu g m L^{-1}\right) \\
\pm S D \\
\end{array}$ & \\
\hline \multirow{3}{*}{ HCTZ } & 2.5 & 2.5 & $2.56 \pm 0.015$ & 0.309 & $2.55 \pm 0.011$ & 0.224 & $5.05 \pm 0.012$ & 0.245 & $2.59 \pm 0.008$ & 0.157 \\
\hline & 5 & 5 & $5.04 \pm 0.017$ & 0.173 & $5.04 \pm 0.008$ & 0.083 & $10.04 \pm 0.013$ & 0.125 & $5.11 \pm 0.023$ & 0.225 \\
\hline & 7.5 & 7.5 & $7.56 \pm 0.016$ & 0.13 & $7.56 \pm 0.017$ & 0.144 & $12.06 \pm 0.015$ & 0.125 & $7.56 \pm 0.005$ & 0.038 \\
\hline \multirow{3}{*}{ EPR } & 7.5 & 7.5 & $7.57 \pm 0.017$ & 0.338 & $7.57 \pm 0.015$ & 0.299 & $5.07 \pm 0.015$ & 0.29 & $7.53 \pm 0.017$ & 0.339 \\
\hline & 15 & 15 & $15.16 \pm 0.030$ & 0.296 & $15.17 \pm 0.014$ & 0.138 & $10.17 \pm 0.022$ & 0.216 & $15.17 \pm 0.026$ & 0.257 \\
\hline & 22.5 & 22.5 & $22.59 \pm 0.017$ & 0.141 & $22.50 \pm 0.030$ & 0.247 & $12.20 \pm 0.022$ & 0.184 & $22.59 \pm 0.015$ & 0.124 \\
\hline
\end{tabular}


Table 3: Characteristic parameters of the calibration equations for the proposed UV absorbance ratio method for the estimation of HCTZ, EPR.

\begin{tabular}{|c|c|c|c|c|}
\hline Parameters & HCTZ & HCTZ & $E P R$ & $E P R$ \\
\hline Wavelength (nm) & 231 & 271 & 231 & 271 \\
\hline Calibration range $(\mu \mathrm{g} / \mathrm{ml})$ & $0.25-10$ & $0.25-10$ & $6-72$ & $6-72$ \\
\hline Detection limit $(\mu \mathrm{g} / \mathrm{ml})$ & 0.256 & 0.013 & 0.268 & 0.050 \\
\hline Quantitation limit ( $\mu \mathrm{g} / \mathrm{ml})$ & 0.776 & 0.041 & 0.811 & 0.150 \\
\hline $\begin{array}{l}\text { Regression equation }(\mathrm{Y})^{\mathrm{a})} \text { : } \\
\text { Slope (b) }\end{array}$ & $5.28 \times 10^{-2}$ & $6.48 \times 10^{-2}$ & $5.20 \times 10^{-2}$ & $1.82 \times 10^{-2}$ \\
\hline $\begin{array}{l}\text { Standard deviation of the slope } \\
\left(\mathbf{S}_{\mathrm{b}}\right)\end{array}$ & $3.94 \times 10^{-4}$ & $2.72 \times 10^{-5}$ & $3.64 \times 10^{-4}$ & $3.16 \times 10^{-5}$ \\
\hline $\begin{array}{l}\text { Relative standard deviation of } \\
\text { the slope }(\%)\end{array}$ & 0.746 & 0.042 & 0.70 & 0.173 \\
\hline Confidence limit of the slope ${ }^{b)}$ & $4.80 \times 10^{-2}-6.50 \times 10^{-2}$ & $6.40 \times 10^{-3}-6.56 \times 10^{2}$ & $5.00 \times 10^{-2}-5.40 \times 10^{-2}$ & $1.73 \times 10^{-2}-1.93 \times 10^{-2}$ \\
\hline Intercept (a) & $5.7 \times 10^{-3}$ & $4.60 \times 10^{-3}$ & $4.0 \times 10^{-3}$ & $-4.83 \times 10^{-3}$ \\
\hline $\begin{array}{l}\text { Standard deviation of the } \\
\text { intercept }\left(S_{a}\right)\end{array}$ & $7.7 \times 10^{-4}$ & $0.26 \times 10^{-4}$ & $4.20 \times 10^{-3}$ & $2.7 \times 10^{-4}$ \\
\hline $\begin{array}{l}\text { Confidence limit of the } \\
\text { intercept }{ }^{b}\end{array}$ & $\begin{array}{c}\left(-9.2 \times 10^{-2}\right)-(8.09 \\
\left.\times 10^{-2}\right)\end{array}$ & $\begin{array}{l}\left(-3.43 \times 10^{-3}\right)- \\
\left(1.25 \times 10^{-2}\right)\end{array}$ & $\begin{array}{l}\left(-1.58 \times 10^{-2}\right)- \\
\left(2.38 \times 10^{-2}\right)\end{array}$ & $\begin{array}{l}\left(-1.46 \times 10^{-2}\right)- \\
\left(0.49 \times 10^{-2}\right)\end{array}$ \\
\hline Correlation coefficient (r) & 0.9996 & 0.9999 & 0.9998 & 0.9995 \\
\hline Standard error of estimation & $0.9 \times 10^{-2}$ & $11.59 \times 10^{-2}$ & $6.50 \times 10^{-3}$ & $4.44 \times 10^{-1}$ \\
\hline
\end{tabular}

\subsubsection{Linearity and range}

Different concentrations of standard solution in the range of linearity $(0.25-10 \mu \mathrm{g} / \mathrm{ml})$ for HCTZ, and $(6-72 \mu \mathrm{g} / \mathrm{ml})$ for EPR, and synthetic mixtures were prepared as described in the analytical method and were measured on UV as three replicates of each concentration of each analyte and mixture.
A linear relationship was found and the results were evaluated by calculating the regression line by the method of least squares. The correlation coefficient (r), Slope and y-intercept were calculated. The high value of correlation coefficient $\left(r^{2}>0.999\right)$ indicated that method was linear. (Table 3 ) showed the raw data of linearity. 
Table 4: Accuracy results of developed UV absorbance ratio method for determination of HCTZ and EPR

\begin{tabular}{|c|c|c|c|c|c|c|}
\hline $\begin{array}{c}\text { API } \\
\text { HCTZ } \\
\text { EPR }\end{array}$ & $\begin{array}{l}\text { \% recovery } \\
2.5 \mu \mathrm{g} / \mathrm{mL} \\
7.5 \mu \mathrm{g} / \mathrm{mL}\end{array}$ & $\begin{array}{c}\text { \%recovery } \\
5 \mu \mathrm{g} / \mathrm{mL} \\
15 \mu \mathrm{g} / \mathrm{mL}\end{array}$ & $\begin{array}{c}\text { \% recovery } \\
7.5 \mu \mathrm{g} / \mathrm{mL} \\
22.5 \mu \mathrm{g} / \mathrm{mL}\end{array}$ & $\begin{array}{l}\text { Mean } \\
\text { recovery }\end{array}$ & SD & RSD \\
\hline HCTZ & 99.54 & 99.29 & 101.36 & 99.43 & 1.18 & 1.18 \\
\hline EPR & 100.47 & 99.96 & 101 & 101.11 & 0.95 & 0.94 \\
\hline
\end{tabular}

Table 5: Results of analysis of pharmaceutical product using developed UV absorbance ratio method for determination of HCTZ and EPR in Teveten plus 600/25 mg tablets.

\begin{tabular}{|c|c|c|c|c|}
\hline API determined & Product & $\begin{array}{c}\text { Concentration level } \\
(\mu \mathrm{g} / \mathrm{ml})\end{array}$ & $\begin{array}{c}\text { Recovery (\%) } \\
\text { developed method }\end{array}$ & $\begin{array}{l}\text { Recovery (\%) } \\
\text { Pharmacopeia } \\
\text { method }^{a)}\end{array}$ \\
\hline \multirow{7}{*}{ HCTZ } & \multirow{7}{*}{$\begin{array}{l}\text { Teveten plus } \\
\text { 600/25 mg } \\
\text { tablets } \\
\text { (B.no 637575) }\end{array}$} & 0.25 & 100.40 & 100.24 \\
\hline & & 0.5 & 99.50 & 100.01 \\
\hline & & 1 & 100.36 & 99.88 \\
\hline & & 2 & 99.38 & 100.82 \\
\hline & & 3 & 100.09 & 99.07 \\
\hline & & Mean & 99.95 & 100.00 \\
\hline & & \pm S.D & 0.48 & 0.63 \\
\hline \multirow{7}{*}{ EPR } & \multirow{7}{*}{$\begin{array}{l}\text { Teveten plus } \\
600 / 25 \mathrm{mg} \\
\text { tablets } \\
\text { (B.no 637575) }\end{array}$} & 6 & 100.32 & 100.2 \\
\hline & & 12 & 99.57 & 99.89 \\
\hline & & 24 & 99.26 & 99.39 \\
\hline & & 48 & 100.08 & 100.05 \\
\hline & & 72 & 101.00 & 100.63 \\
\hline & & Mean & 100.05 & 100.03 \\
\hline & & \pm S.D & 0.68 & 0.45 \\
\hline
\end{tabular}

${ }^{a)}$ USP 42 for HCTZ [3], Published method of analysis for EPR and HCTZ [34]. 
Table 6: calculating student t-test and F-ratio for developed UV absorbance ratio method for determination of HCTZ, and EPR by comparing mean and standard deviation of developed UV absorbance ratio method and published analytical methods for determination of studied APIs.

\begin{tabular}{|c|c|c|c|}
\hline \multirow{2}{*}{ API determined } & Calculation & $\begin{array}{c}\text { Recovery (\%) } \\
\text { developed method }\end{array}$ & $\begin{array}{c}\text { Recovery (\%) } \\
\text { Pharmacopeia } \\
\text { method }^{\text {c }}\end{array}$ \\
\hline \multirow{3}{*}{ HCTZ } & Mean \pm S.D & $99.95 \pm 0.48$ & $100.00 \pm 0.63$ \\
\cline { 2 - 4 } & t-test & 0.12 & $2.45^{\text {a) }}$ \\
\cline { 2 - 4 } & F-ratio & 1.72 & $5.05^{\text {b) }}$ \\
\hline \multirow{3}{*}{ EPR } & Mean \pm S.D & $100.05 \pm 0.68$ & $100.03 \pm 0.45$ \\
\cline { 2 - 4 } & t-test & 0.05 & $2.45^{\text {a) }}$ \\
\cline { 2 - 4 } & F-ratio & 2.28 & $5.05^{\text {b) }}$ \\
\hline
\end{tabular}

a) Theoretical $\mathrm{t}$ tabulated at degree of freedom $4,{ }^{\mathrm{b})}$ Theoretical $\mathrm{F}$ tabulated at degree of freedom $4,{ }^{c)}$ USP 42 for HCTZ, Published method of analysis for EPR.

\subsubsection{Accuracy results}

Placebo, blank and standard solution were measured firstly by UV spectrophotometer, placebo was prepared as formula without active ingredients to test if any of components of the formula interfere the formula. Blank is the solvent used for standard and sample preparation was tested for insurance that no solvents interfere with studied APIs. To the pre analyzed formulation, a known amount of raw material was added and it can be analyzed by the proposed method.

To an accurately weighed quantity of the tablet powder equivalent to $6 \mathrm{mg}$ of EPR and $0.25 \mathrm{mg}$ HCTZ , 7.5, 15 and $22.5 \mathrm{mg}$ of EPR and 2.5, 5 and $7.5 \mathrm{mg}$ of HCTZ raw materials were added into a series of $100 \mathrm{ml}$ volumetric flasks. The procedure was repeated as per the analysis of formulation. The amount of each drug recovered was calculated. The procedure was repeated for three times for each concentration. Eighteen determinations that the results were tabulated and percentage recovery was calculated in (Table 4). The value of the mean recovery obtained $(98-102 \%)$, indicated that the method was accurate.

\subsubsection{Stability of standard solution:}

Stability study was performed by using stock standard solution of HCTZ, EPR, and mixture at room temperature for 24 hours and at $4^{\circ} \mathrm{C}$ for 30 days. All stability studies were conducted at concentration $8 \mu \mathrm{g} / \mathrm{ml}$ with 3 determinations for each. Standard solution was found stable as RSD of all replicate determinations was not more than $2 \%$.

\subsubsection{Analysis of pharmaceutical product:}

The proposed UV spectrophotometric method was applied to simultaneous estimation of HCTZ and EPR in Teveten plus 600/25 mg tablets (Abott B.no 637575 ) results indicated in (Table 5).

According to previous results student t-test and Fratio were calculated and tabulated for each of studied APIs. The results of determination of EPR and HCTZ combined in commercial tablets obtained from the proposed method were compared with published method of analysis of HCTZ and EPR (G S et al., 2011). Statistical comparison of the results was performed with regards to accuracy and precision using student's t-test and the F-ratio at $95 \%$ confidence level (Table 6). There is no significant difference between the two methods with regard to accuracy and precision.

\section{Conclusion:}

A simple, efficient, fast method for quantitative analysis of HCTZ and EPR was developed. The method was validated according to $\mathrm{ICH}$ guidelines and was found to be specific, linear, sensitive, robust, precise and accurate. The method was 
simple, direct and no derivatization step was needed. The method was successfully applied to the analysis of studied drugs in their commercial pharmaceutical products. simple, direct and no derivatization step was needed. The method was successfully applied to the analysis of studied drugs in their commercial pharmaceutical products.

\section{References:}

Anandakumar, K., Jothieswari, D., Vetrichelvan, T., Santhi, Dv., \& Subathrai, R. (2011). Development and validation of a UV spectrophotometric method for the simultaneous estimation of eprosartan mesylate and hydrochlorothiazide in bulk and formulations. Indian Journal of Pharmaceutical Sciences, 73(5), 569.

Bhupendra, P. D., Manohar, S. D., Bhanudas, S. R., \& Kailas, B. J. (2016). UV Spectrophotometric Method for Estimation of Eprosartan Mesylate in Bulk and in Pharmaceutical Formulation. Asian Journal of Pharmaceutical Analysis, 6(2), 119.

chandana, o. s. s., kumar, d. s., \& babu, r. r. (2016). Method development and validation of eprosartan mesylate and its impurities using reverse phase high-performance liquid chromatography. international journal of current pharmaceutical research, 8(4), 49.

G S, D., Sudhakar, M., \& Rao, J. V. (2011). Simultaneous Determination of Eprosartan Mesylate and Hydrochlorthiazide in Pharmaceutical Dosage form by Reverse Phase High Performance Liquid Chromatography. Pharmaceutica Analytica Acta, 02(03).

Guideline, I. H. T. (2005). Validation of analytical procedures: Text and methodology Q2 (R1). International Conference on Harmonization, Geneva, Switzerland, 11-12.
Hacioglu, F., \& Onal, A. (2012). Determination of Eprosartan Mesylate and Hydrochlorothiazide in Tablets by Derivative Spectrophotometric and High-Performance Liquid Chromatographic Methods. Journal of Chromatographic Science, 50(8), 688-693.

Mohammed, N. S., \& Mohammed, A. J. (2016). Development and Validation of RP-HPLC Method for the Determination of Hydrochlorothiazide in Bulk Drug and Pharmaceutical Dosage Form. Chromatography Research International, 2016, 17.

Rajamahanti, S. G., Annapurna, N., Santosh, T., Durga, B., \& Raziya, Sk. (2017). Simultaneous Estimation of Eprosartan and Hydrochlorthiazide in Pharmaceutical Dosage Forms by RP-HPLC. Asian Journal of Chemistry, 29(5), 1091-1094.

Shah, J. V., Parekh, J. M., Shah, P. A., Shah, P. V., Sanyal, M., \& Shrivastav, P. S. (2017). Application of an LC-MS/MS method for the analysis of amlodipine, valsartan and hydrochlorothiazide in polypill for a bioequivalence study. Journal of Pharmaceutical Analysis, 7(5), 309-316.

Singh, B., Lokhandae, R. S., Dwivedi, A., Sharma, S., \& Dubey, N. (2014). Improved simultaneous quantitation of candesartan and hydrochlorthiazide in human plasma by UPLC-MS/MS and its application in bioequivalence studies. Journal of Pharmaceutical Analysis, 4(2), 144-152.

Tw, H. (2018). Determination of Hydrochlorothiazide in Plasma by High Performance Liquid Chromatography (HPLC). Open Access Journal of Pharmaceutical Research, 2(1). 